\title{
Media Policy, Democracy and Theories of the Press
}

In Western democracies, most arguments about media policy are premised on normative theories of the press (Christians et al. 2009, p. 5). These arguments are inspired by the idea that the media are entrusted with information power and how this power is used has consequences for democracy (Stromback 2005, p. 335). This chapter discusses some of the theories and ideologies on which arguments about media policy reform are predicated. An understanding of these theories is essential for the comprehension of these arguments. The normative theories discussed in this chapter include the neoliberal variant of the libertarian theory and the ideology of social democracy. The concepts of libertarianism and social responsibility are examined to provide background information on the neoliberal theory of the press. To emphasise the important role the media play in sustaining self-governance through citizens participation in public debates, I explore relevant conceptualisations of the public sphere. Specifically, Habermas' (1989) concept of a central public sphere; Fraser's (1992) conceptualisation of multiple publics and Ornebring and Jonsson's (2004) application of Fraser's concept of multiple publics are critically analysed. 'Journalism as an interpretive community', a concept put forward by Zelizer (1993), is expounded to show that in debates about their profession, the press can function as an interpretive community, multiple homogeneous publics and individual unique voices.

The media have become a very important part of contemporary human affairs (McQuail 2010, p. 162). Information on a wide variety of subjects

(C) The Author(s) 2020

B. Ogbebor, British Media Coverage of the Press Reform Debate, https://doi.org/10.1007/978-3-030-37265-1_4 
ranging from lifestyle to political issues can be accessed through the media. Top of the scale of the media's relevance to society is its role in the sustenance of democracy (Christians et al. 2009, p. 55). It has been argued that democracy cannot survive in contemporary society without the news media (Lee-Wright et al. 2012, p. 3). There is a wide consensus that the media ought to carry out certain functions in a democratic society (Schudson 2008). Though the views of scholars on the extent to which they do and ought to do this vary, many agree that one of the media's roles is to check on government to see that they are accountable to society (Lee-Wright et al. 2012, p. 3). The media are also expected to serve as the communication link between the public and political leaders, often acting as the voice of the people as well as advocate of the oppressed and less privileged. That is why any threat to responsible journalism is viewed by many as a threat to democracy.

It is widely accepted that what legitimates the media is their role in the sustenance of democracy (Franklin 2004; Herman and Chomsky 2008). This view is, however, not without contestation. Some analysts have described the claim as both a "stereotype and a myth" (Merrill 2000; Graber 2003). The latter argument may hold water when viewed against the background that the media and indeed journalism exist in nations that do not practice democracy. In such nations, the media serve as an instrument of propaganda (Scammell 2000) and not as an agent of democracy. However, in today's liberal democracies, the media play a vital role in the growth and sustenance of democracy. Since "democracy" is a broad term, it is important to clarify the type of democracy this book is concerned with. There are diverse definitions of democracy yet two major divides: the minimalist and maximalist definitions (Lipset and Lakin 2004, pp. 19-22). While the minimalist definition focuses on democracy as a system in which adult citizens of a community have the right to vote in a leader of their choice (Schumpeter 1943, cited in Saxer 2013, p. 5), the maximalist approach to democracy goes beyond the political sphere to include social and economic values, such as freedom to receive and give information, freedom of association, equal opportunities and press freedom (Ewald 2013 , p. 52). The maximalist approach is based on the idea that all aspects of society should be run democratically. In other words, democracy can be practiced in different domains of life, such as in the media, business, nongovernmental organisations, meetings, families and schools.

Unlike the minimalist approach to democracy, which is based on the elitist view of Schumpeter (1943) where democracy is confined to an elite 
group voted into power by the people, maximalists see democracy as a system of government in which power rests with the populace, not only their right to vote in a leader of their choice but also their right to equal participation in public debates through which they could influence decisions that affect them (Cheema 2005, p. 4). As stated earlier, this book is concerned with the maximalist approach to democracy. Therefore, the definition of democracy as "governance by the people, for the people and of the people" (Lincoln 1863/2009) is interpreted in this book as the ability of "the people" (citizens) to take part in governance, not only by voting in the right leader, but also by taking part in public debates that can influence policy decisions (Gunther and Mughan, cited in Christians et al. 2009 , p. 25). This book engages with the maximalist approach to democracy. Did the media play its role of sustaining democracy through its facilitation of citizens' participation in the media policy that followed the News of the World phone hacking scandal? This book provides answers to this question. It takes the position that creative and effective ideas for media reform can emerge from the press if it serves as a democratic space for public debates.

It is widely acknowledged that democracy is the best form of government (Dahl et al. 2003, p. 29). However, this view is not without contestation. Some philosophers like Plato (cited in Dahl et al. 2003) and Aristotle in his The Politics $(2010,335-323$ BC) have questioned the endorsement of democracy as the ideal form of government. Towing this line, scholars like Merrill (2000), Graber (2003) and Barry (2011) argue that democracy is not necessarily the ideal type of government but that each country should be allowed to develop the style of government that best suits their culture (Merrill 2000, pp. 197-199). However, several empirical studies have identified democracy as a popular form of government (Norris 1999; Dahl et al. 2003). Though Dahl et al. (2003, p. 29) admit that "democracy is not an unmitigated blessing", they contend that its advantages far outweigh its shortfalls. The latter argument is the position of this book. Democracy is important because it promotes human rights including freedom of expression (Dahl et al., ibid.). In an age where freedom of the individual to speak, be informed and publish is recognised as universal human rights, democracy promotes freedom as no feasible alternative can (Dahl 1989, pp. 88-89).

As the former UK Prime Minister Winston Churchill said, "Democracy is the worst form of government, except for all those other forms that have been tried from time to time" (Mishler and Rose 1999, cited in Richard 
et al. 2009, p. 23). It is worthy of note that despite arguments for and against democracy, it has emerged as the choice system of government in the twenty-first century (Held 2006, p. 1). Countries with strikingly different political systems have all claimed to be democratic (Held 1996, p. 1; Manza and Uggen 2006, pp. 17-18) but there is a great difference between actual and ideal democracy (Sartori 1987, pp. 7-8). Actual democracy refers to the definite way the concept is practiced in a specific group while ideal democracy is normative. Some scholars have argued that going by the definitions of democracy, ideal democracy is impracticable (Wolff 2013, p. 11). Does this imply that evaluating media coverage based on normative theories of the press in a democracy is asking too much of the media? The following section attempts to answer this question by reviewing relevant literature on normative theories of the press in a democratic society.

\section{Normative Theories and Media Policy}

Normative theories relate to expectations from citizens on how the media ought to operate in order to achieve or maintain prevailing social values (McQuail 2010. p. 14). The media have been entrusted with the task of controlling information, a role which is integral to the success of any democracy. Scholars argue that since the public has entrusted this power to the media, with which it can hold power to account, set the agenda of public discourse and perhaps shape public opinion, the public has the right to make some demands of the media- a kind of implicit contractual agreement (Kovach and Rosenstiel 2003, pp. 51-52). Normative theories make allowances for journalism to be analysed based on moral obligations. Many scholars accept that the overarching moral obligation of the press is to protect democracy (Carey 1997, p. 332, cited in Schudson 2008, p. 11). Consequently, normative theories of the press provide foundations for arguments on how the media can sustain democracy. Some analysts contend that normative theories promote ideals that are not achievable and as such ought to be abandoned (Hallin and Mancini 2004).

This book takes the position that though normative theories may not be 100 per cent achievable, they serve as ideal models for people to aspire to, in order to achieve acceptable press standards (Wolff 2013, p. 11). Siebert et al.'s (1956) four theories of the press are largely accepted as the maiden academic attempt at providing normative theories of the press. Siebert et al. (1956) advanced four theories, namely the authoritarian, the 
Soviet communist, the libertarian and the social responsibility theories. These "theories" have come under heavy criticism due to their inconsistent conceptual framework, inability to provide acceptable universal press theories and failure to contain the diversity of media forms (Hallin and Mancini 2004). Despite these shortcomings, Siebert et al.'s (1956) normative models, particularly their libertarian theory, are still very applicable to the study of the coverage of media policy in Western nations like Britain (McQuail 2010, p. 176).

In Western democracies, such as Britain, participants in media policy debates propagate ideas based on the libertarian theory. Though the libertarian theory has been modified over the years, exploring it in its original form will help us understand its variants during debates about press reform. Much of the commercial press in Britain propagate ideas about media policy that draw from the libertarian theory. The libertarian theory advocates that the press should be a marketplace of ideas where diverse views can be aired without fear of suppression or oppression (Siebert et al. 1956, p. 70 ). It posits that the press should be a medium through which arguments, opinions and evidences are presented to the public on the basis of which they can check on the powerful and make informed decisions (Siebert et al. 1956, p. 3). Proponents of this theory argue that the press should be autonomous and free from every form of state regulation because a state-regulated press cannot call the government to account (Scammell 2000). They contend that a state-regulated press will hamper efforts to expose corrupt politicians; that it will serve as a clog in the wheel of journalists' efforts to equip the public with the information they need to contribute intelligently to public debates and make informed decisions on other areas of life.

Libertarian theory warns that journalism cannot function as the watchdog of society without press autonomy. The theory claims that press accountability will be provided for by the media market. It argues that competition to gain readership will motivate the press to represent a wide range of views and perspectives in society (Siebert et al. 1956, p. 71; McQuail 2010, p. 176). This perspective assumes an active audience whose patronage or withdrawal of patronage will compel publishers to serve the interest of the public (Biagi 2014, p. 348). Though the libertarian theory claims to protect democracy through its watchdog and information roles, the theory has been criticised by several scholars for having negative implications for democracy (Glasser 1986, p. 93, cited in McQuail 2010 , p. 176). Christened "negative freedom" because of its resistance to 
state intervention (Berlin 1969, cited in Pickard 2013, p. 343), the libertarian concept of press freedom has often been described as freedom for publishers to publish whatsoever they wish without any form of responsibility (Curran and Seaton 2010). It can be argued that the libertarian concept of press freedom serves the business interests of media owners and makes it easier for the press to encroach on the liberty of others (Pickard 2015).

The libertarian claim that accountability will be provided for by competitiveness in the media market is questionable because history has shown that rather than ensure accountability, competitive media markets have instead triggered anti-democratic practices (Fenton 2011; Dawes 2013). Fenton (2011, n.p.) asserts that "markets do not have democratic intent at their core" because when markets come under pressure, ethics are brushed aside in pursuit of commercial profit. In defence of the libertarian "market accountability" claim, Bettig and Hall (2012, pp. 16-17) argue that the role the media have played over the years in exposing journalistic scandals is proof that "the media market place is free and competitive enough to ensure that the truth generally prevails". Bettig and Hall, however, agree that such self-policing leaves serious gaps in press coverage of media issues (ibid.). Similar criticisms of the press gave rise to the notion of social responsibility (McQuail 2010).

The notion of "social responsibility" was initiated by the 1947 Hutchins Commission on freedom of the press in the USA (McQuail 2010, pp. 170-171). The Commission was set up in response to widespread criticism of the American press, and particularly its sensationalism, commercialism, ownership concentration, the alleged abuse of its powers and the consequent need to ensure press accountability (Hartley 2011). In tandem with the philosophy of the social contract, the social responsibility model of the liberal theory argues that freedom to receive and disseminate information should be accompanied by some form of responsibility to the public: what scholars refer to as "positive freedom" (Berlin 1969; Pickard 2015 , p. 40). This responsibility, it states, should include not only the representation of comprehensive, factual and accurate reports but also the promotion of public debates (Commission on Freedom of the Press 1947, pp. 21-27).

Unlike the libertarian theory, the notion of social responsibility sees a place for government intervention in media accountability systems (Biagi 2014 , p. 348). It posits that where the news media fall short in their responsibility to society, a public agency or government should be allowed 
to intervene to ensure press accountability. The Hutchins Commission (Commission on Freedom of the Press 1947) puts it this way:

The media has an obligation to be socially responsible; to see that all sides are represented and that the public has enough information to decide; and that if the media do not take on themselves such responsibility, it may be necessary for some other agency of the public to enforce it. (cited in Siebert et al. 1956, p. 5)

So, unlike the libertarian theory which sees no place for government intervention in ensuring press accountability, the notion of social responsibility welcomes external participation in matters of the press, if the press falls short of its responsibility to society. Though it agrees with the libertarian theory that press self-regulation and press freedom are integral to the fulfilment of the media's informational and watchdog role, its concept of press freedom differed from the libertarian perspective. Though many of the proposals of the Hutchins Commission (Commission on Freedom of the Press 1947) were criticised and rejected by the commercial press, the Commission can be credited for an improved consciousness of the need for responsible journalism in the commercial press in several countries including the UK (Pickard 2015, p. 187). The report of the Hutchins Commission served as exhibit or information for national and international debates on media policy, particularly, on the role of the press in a democracy. For instance, Britain's first Royal Commission on the press is recorded to have used documents from the Hutchins Commission as exhibits (Pickard 2015, p. 188).

One perspective views the notion of social responsibility as an improvement on the libertarian press theory (Nerone et al. 1995). For those with this view, the notion of social responsibility is a more public service-oriented model of the liberal theory: one that makes room not only for the press but also for the public (McQuail 2010, p. 184). A different perspective contends that the social responsibility model only led to weak reforms (Curran and Seaton 2010, p. 338). Those with this view argue that rather than replace the libertarian theory, as claimed by some scholars, the social responsibility concept "essentially enabled a slightly tweaked libertarian model to continue to prevail unabated" (Pickard 2015, p. 195). By the 1970s, a variant of libertarianism known as neoliberalism had become the hegemonic ideology in debates on media policy (Plehwe et al. 2006, p. 39; Phelan 2014). The neoliberal ideology remains rife in contemporary 
debates about press policy; as such it will form part of the framework for my analysis of how the press covered the media policy debate that followed the NoTW phone hacking scandal, especially the debate on freedom of the press.

The neoliberal theory of the press took its origins from the broad concept of neoliberalism. The term "neoliberalism" was formed by participants at the Walter Lippman Colloquium in Paris in 1938, in a bid to describe their desire to reconstruct classical laissez-faire liberalism (Jones 2012 , p. 6, cited in Davis 2016, p. 29). It was defined by the colloquium as "the priority of the price mechanism, the free enterprise, the system of competition, and a strong and impartial state" (Livingstone 2013, p. 436). Key proponents of the ideology include Milton Friedman and Austrian School economists Ludwig von Mises and Friedrich Hayek (Plehwe et al. 2006 , p. 18). In later years, it became associated with the free trade, deregulation and privatisation moves of former UK Prime Minister Margaret Thatcher and former US President Ronald Reagan (Springer et al. 2016, p. 144). The ideology has gone through several modifications and cultural transformations since then (Hayek 1944; Friedman 1962; Harvey 2005). Neoliberalism in its contemporary form is "a theory of political economic practices that proposes that human well-being can best be advanced by liberating entrepreneurial freedoms and skills within an institutional framework characterized by strong property rights, free market and free trade" (Harvey 2005, p. 2). Freedom is a major feature of the neoliberal theory. Neoliberalism, which is a variant of libertarianism, advocates what has been described as the "negative" view of freedom where, as explained earlier, press freedom is interpreted as freedom from state interference. This contrasts with the positive liberty advanced by left-wing ideologists (Phelan 2014).

According to the neoliberal ideology, the role of the state is to create a conducive environment for the private sector to thrive in businesses and that includes intervening to prevent market failure (Harvey 2005, p. 2 ). In relation to media self-coverage, an example of a neoliberal argument would be that the government should intervene in media regulation only to ensure fair play in media ownership. Proponents of the neoliberal theory believe that by intervening to save private businesses, the state indirectly caters for the needs of individuals in society because entrepreneurs are then able to offer jobs and other deliverables to society (Harvey 2005). The neoliberal ideology posits that government involvement in business poses a threat to freedom, and that "the market, as a self-organising 
system in which individuals freely choose to participate, is best suited to guarantee freedom" (Mayes 2015, p. 35). So, while the pure libertarian theory refuses any role for the state, its neoliberal variant, just like the social responsibility model, approves of a small role for the state but in its case, that role should be to prevent market failure (Harvey 2005, p. 2).

The neoliberal theory of the press refers to a situation in which the media is viewed primarily as a business enterprise. From the neoliberal press perspective, the press should be commercially or privately owned; the press must be self-regulated so as to have the autonomy it needs to call the powerful to account and fulfil its informational role in a democracy; it should serve the public interest (though what this means is contested; see Chap. 2); a small role for the state is acceptable, for example, in the making and implementation of laws that guarantee fair competition in the media business (McChesney 2001). Other aspects such as service and accountability, it contends, should be left in the hands of the media's selfregulatory bodies and the market (ibid.). Neoliberal conceptualisation of press freedom is hegemonic (commonsensical) in discourses about media policy (Lichtenberg 1990; Phelan 2014). Alternative interpretations of press freedom are often marginalised or presented as illogical in the light of hegemonic neoliberal interpretations of what guarantees a free press (Putnis 2000; Curran and Seaton 2010).

However, counter-hegemonic discourses labelling the neoliberal theory of the press as anti-democratic and calling for more public interest journalism appear to be on the rise (Schlosberg 2017). For instance, the theory of social democracy has emerged as a major challenger of the neoliberal hegemony in debates about media policy (Pickard 2015). Social democracy as an ideology emerged in the mid-twentieth century following decisions by Western socialists to revise their goals. One way they did this was to reform rather than abolish capitalism (Heywood 2017, p. 123). Social democracy aims to correct the fundamental defects of capitalism and "pursue goals that reduce the inequalities that exist within the system" (Lightfoot 2005, p. 17). It posits that capitalism is "a morally defective means of distributing resources, because of its tendency towards poverty and inequality" (Heywood 2017, p. 123). The social democratic ideology contends that the defects of the capitalist system can be corrected through both economic and social interventions (Miller 1998, cited in Craig 2000, p. 836). The theory of social democracy is based on this ideology. 
Proponents of the social democratic theory are critical of the "negative liberty" advanced by the neoliberal variant of the libertarian theory where press freedom is interpreted as freedom from state interference (Meyer and Hinchman 2007). The theory sees the state as the custodian of public interest journalism, and as such, it accepts state intervention in press regulation to guarantee press accountability (Meyer and Hinchman 2007). Cushion (2012, p. 198) and Lichtenberg (1990, p. 105) agree that some level of statutory regulation can enhance rather than impede democracy. Critics of social democracy argue that the theory is idealistic, vague and sounds like a socialist compromise to capitalism or "capitalism-lite" (Keane 2016). One of the major criticisms against the theory of social democracy is that it underestimates the possibility of state intervention to impact negatively on press freedom. Though these concerns are not inconsequential, studies have demonstrated that a mechanism can be put in place to ensure that statutory regulation does not impede the media from fulfilling their watchdog role in a democracy (Humphreys 1996, p. 107). There is, however, no denying the fact that measures to check the abuse of government intervention in press regulation have not always been successful (Badsey 2013 , p. 67). The bottom line is that both theories have pros and cons. The focus of this discussion is not to advocate one theory over another but to acquaint the reader with the two major theories on which debates on media policy are based and to argue that both theories have strengths and weaknesses and none of these two should be hegemonic in debates about media policy. In a democracy, the media ought to be a democratic public sphere (Habermas 1989; Fraser 1992). The following section explores the concept of the media as a democratic public sphere during debates about media policy.

\section{The Media as a Democratic Public Sphere}

Habermas conceptualises the public sphere as an arena where people meet to discuss societal concerns and through their arguments influence political decisions (Habermas 1989; Garcia-Blanco et al. 2009). According to Habermas, equality was brought about by a complete disregard for status because decisions were not based on societal standing but on the best rational argument (Habermas 1989, p. 4). The author observed that in the late seventeenth and early eighteenth centuries, coffee houses, salons and clubs were meeting points for these public deliberations. In modern democracies, discussions in salons (coffee shops and bars) rarely carry the 
same weight due to the large numbers of people that make up most political communities today. This places a premium on the role of the media as a democratic public sphere: a public space where citizens can debate issues that concern them. According to Habermas' $(1989$, p. 83) account of the "golden age of the liberal public sphere", discussions were centred on issues of common concern and citizens were able to set aside individual preferences and arrive at a consensus based on "the common good".

However, from the late nineteenth century, the public sphere began to degenerate, and the quest for profit began to override public interest journalism (Habermas 1989). Facilitators of debates in the media's public sphere became more concerned about "what interests the public" rather than what was "in the public interest" with the goal being to increase readership and attract advertisers. This degeneration of the public sphere manifested itself in the trivialisation of news content. The result was that citizens became a consumer audience, mainly interested in being entertained and consuming dumbed down information (Habermas 1989, p. 164; Franklin 1997). The media assuaged this appetite by inundating this space with infotainment (information plus entertainment). A degenerated public sphere in relation to the coverage of media policy can mean shifting focus from in-depth analysis of key issues of concern in press standards to infotainment and other trivial news relating to media policy. Infotainment can be detrimental to media policy debates because it can promote ignorance on the subject by presenting to readers sensational news rather than in-depth analysis of key issues of concern. As Barber $(1999$, p. 582) points out, public ignorance is detrimental to democracy because a citizenry without sufficient information may not be able to adequately evaluate the alternatives before them and could, as a result, advocate policies that are harmful to society.

This book argues that the degeneration of the public sphere is more complex than previous studies have shown. Most studies on the media as a public sphere have focused on the media representation of others and not of themselves. As such, scholars did not take into consideration the commodification of a public sphere in which the deliberation relates to the facilitator of the sphere. The result was that commercialism was limited to prioritisation of gains made from advertising ("selling customers to advertisers"), adopting paywalls and direct product sales (McQuail 2010, pp. 222-224), whereas in the media coverage of debates on journalism, commodification of the public sphere can go beyond the aforementioned to the prioritisation of the media's personal interests (giving priority to the 
promotion of the newspaper's argument in the debate). In this case, the media's personal interests can override "what interests the public". One feature of Habermas' (1989, pp. 189-193) degenerated public sphere that can be seen in the coverage of media policy is that commercial interest (the interest of media owners) merges with the interests of policymakers, to turn the public sphere from a democratic forum for public debate into a capitalist haven where prioritisation of profit becomes the order of the day (Habermas 1989, pp. 189-193). Profit goes beyond financial gains to successful advancement of one's ideology in an argument, good press coverage for policymakers and high readership for newspapers which can earn their owners power of influence and the patronage of advertisers. Habermas sees advertising as one of the causes of the degeneration of the public sphere (Habermas 1989, pp. 189-193).

It can be argued that job constraints have also led to the degeneration of the public sphere. The pressures brought on journalists by the constraints of their job have been blamed for some of the press' bad behaviour (Shoemaker and Reese 2013, pp. 140-142). Examples of such constraints include limited time of production made worse with the introduction of the 24/7 news routine, financial constraints and, more remarkably, the emergence of digital journalism (ibid.). The coming of the internet has transformed journalism and poses a threat to the continued existence of print journalism (Allan 2006, pp. 2-4). The move of Independent newspaper from print to online intensifies that argument (Independent 2016). While the extinction of the printed press was at the time of writing a contested view (Pavlik 2001; Franklin 2008), there is no doubt that the coming of digital journalism has led to the drop in the readership of print newspapers and the exodus of both readers and advertisers to online platforms (Department for Digital, Culture, Media and Sport 2019). The competition resulting from these has increased the lure of subterfuge as a means of news gathering, the aim being to get scoops that sell. Though the online news had not surfaced at the time Habermas wrote The Structural Transformation of the Public Sphere: An Inquiry into a Category of Bourgeois Society (1989), it can be argued that in the twenty-first century, pressure brought on the printed press by the emergence of digital journalism facilitated the degeneration of the public sphere. The consequence of this for democracy is that providing a democratic platform for public debate is no longer its primary concern. The questions this discussion on degeneration of the public sphere raises are, "in the coverage of the media policy debate that followed the NoTW phone hacking scandal, 
did the media serve as a degenerated public sphere? If so, what impact did this have on efforts at reforming media policy"? Discussions in Chaps. 6, $7,8,9,10$ and 11 will provide answers to these questions.

It is important to point out that there are a number of issues with Habermas' concept of the public sphere. One of the problems is that it is not clear whether Habermas was referring to a historical situation or a normative ideal (Dahlgren 1995). Several scholars have argued that there never existed a public sphere with Habermas' ideal (Schudson 1992; Dahlgren 1995). Those with this view contend that right from the period of Habermas' ideal public sphere, there had always been in the public space trivial and dumbed-down discussions with commercial interest overriding the public interest. This book sides with the argument that Habermas' concept of the public sphere is better employed as normative. The public sphere concept is useful for the analysis of the representation of media policy both in its original form, as used to discuss the degeneration of the public sphere earlier in this chapter, and in modified forms. For example, Fraser's (1992) modification of the concept. However, more modifications are needed before the concept can be effectively used for the analysis of discourse on media policy.

Several scholars have critiqued and modified Habermas' concept of the public sphere. Examples of such modifications are Fraser's (1992) alternative publics and "subaltern counterpublics", where equality is hinged on multiple rather than a single comprehensive public sphere; Chantal Mouffe's (2005a, b) agonistic public sphere, which argues for contestations ('radical' discourse) in place of "consensus building through rational discourse"; and Bennett and Entman's (2001) policy sphere, which refers to the aspect of the public sphere that relates to media representations of governmental policies and decision making. The above list is not exhaustive, and this book does not attempt to examine all criticisms of the public sphere. It will only concern itself with arguments that are relevant to my analysis in this book. One of such relevant modifications is Fraser's (1992) discussion on multiple publics.

Fraser (1992, pp. 117-118) queries four assumptions of Habermas' concept of the public sphere. They are the assumption that it is possible for participants in "a public sphere to bracket status differentials and to deliberate as if they were social equals"; that "a single, comprehensive public sphere" is more democratic than multiple and competing publics; "that discourse in the public sphere should be restricted to deliberation about the common good" and that "a functioning democratic public 
sphere requires a sharp separation" from the state. Fraser (1992) argues that while Habermas lays claims to universality in his ideal public space, his focus on a single public - the bourgeois-excludes some sections of the public such as women who were at the time excluded from public debates (Fraser 1990, pp. 58-60).

Fraser contends that rather than eliminate inequality, bracketing a single public endorses inequality by denying diverse groups and interests, a voice within the public sphere; the result being that the interests of the marginalised groups or persons are overlooked (ibid, p. 77). Fraser's argument is that democracy is enhanced not with a single comprehensive public sphere but with "arrangements that accommodate contestation among a plurality of competing publics" (Fraser 1992, p. 122, cited in Butsch 2007 , p. 5). She referred to these competing publics as alternative publics and "subaltern counterpublics". They are alternative in the sense that each sphere is a "homogenous group rather than a diverse deliberative body" (Warner 2002, cited in Butsch 2007, p. 18) and "subaltern counterpublics" because they are discursive spaces where members of subordinate social groups can introduce counter discourses (Fraser 1992, pp. 123-125).

Her use of the word "contestation" to describe debates between multiple publics links to another critique against Habermas' concept which is that discourse in the public sphere should not be restricted to "deliberation about the common good". Along with scholars like Benhabib (2002) and Mouffe (2005a, b), Fraser (1992) says the common good is difficult to determine; the interest of publics may vary and the demand for consensus may only keep out of debates issues that may later be recognised as being of public interest. As an example, Fraser (1992, p. 129) points to the fact that the issue of violence against women was in the past regarded as a private interest and not "for the common good". It was an issue to be discussed in family settings and not in the public sphere, but feminists forming a "subaltern counterpublic" kept up debate about domestic violence which led to its eventual acceptance as a matter of common concern.

In line with my argument that no theory should be hegemonic in the representation of arguments on media policy, Fraser (1992, pp. 129-131) contends that there should be no limits to the issues and arguments that gain access to the public sphere. According to her, "what will count as a matter of concern will be decided precisely through discursive contestations" (ibid, p. 129). For Fraser, contestations (arguments, alternative views, etc.), rather than a consensus, remain closer to the democratic ideal (ibid.). This shifts the focus from Habermas' deliberative model of 
democracy (where deliberation leads to a consensus within the public sphere) to a participatory model where the focus is access of all concerned to the debate within the public sphere. Consensus can then be reached by policymakers based on the knowledge gathered from informed contestations in the media's public sphere.

Taking a cue from Fraser (1992), Ornebring and Jonsson (2004) applied the concept of multiple public spheres to the press. In their application of the concept, the tabloid press can serve as an alternative public sphere to mainstream media (by mainstream media, they refer to major media outlets such as major newspapers, radio stations and television stations). According to the authors, social media, specialised journals and other media outlets outside the mainstream news can serve as counterpublics from which non-elitist groups can counter dominant elite discourses. I refer to this group as "public sphere as platform". This book argues that the public sphere as platform may or may not be a counterpublic.

In Ornebring and Jonsson's (2004, p. 286), view, participants in a media discourse can also be an alternative public sphere if the participants differ from those who normally dominate the media discourse. I will call this "public sphere as people". The authors also argued that a public sphere can be alternative when "other issues than those commonly debated in the mainstream are discussed - or that issues not even debated at all in the mainstream are discussed in the alternative sphere" (ibid.). I will call that "public sphere as issues". Their fourth mediated alternative sphere model is somewhat duplicitous; it comprises of "ways or forms of debating and discussing common issues than those commonly used in the mainstream media" (ibid.). I will call that "alternative methods as public sphere".

This book adds to this portfolio: the public sphere as discourse. This agrees with Warner's (2002, pp. 413-415) argument that the meaning of "public" cannot be limited to Habermas' elucidation of "the public as people" - the discussants. Warner (2002, p. 414) established that public can also refer to the discourse. In this case, the sphere can be "a public"; a body of discourse, a perspective in a debate, common interest on an issue and such like. This book engages with the concept of the public sphere both as platform and as discourse. It examines "public sphere as platform" in the sense that it explores how the media as platform (mainstream press in this case) serve as a democratic public sphere. It examines "public sphere as discourse" by investigating publics within discourse. Having discussed the importance of the media platform as a democratic public sphere 
earlier in this chapter, I now move on to explore concepts that can facilitate our understanding of the public sphere as discourse. Based on Fraser's (1992) conceptualisation of multiple public spheres, I argue that there can be several discursive publics within journalism's interpretive community.

Zelizer (2004, pp. 12-15) conceptualises journalism as an interpretive community, a notion she borrowed from Stanley Fish's explanation of interpretive communities in relation to literary text (Fish 1980, cited in Zelizer 2004, p. 13). An interpretive community consists of "people engaged in common activities and common purposes who employ a common frame of reference for interpreting their social setting" (Berkowitz and Terkeurst 1999, p. 127, cited in Carlson 2015, p. 3). Interpretive communities affect how a phenomenon is interpreted (Zelizer 2004, pp. 13-14). Applying this to journalism, Zelizer (2004) argues that a person's view of journalism will be affected by the person's background, perspectives or the field in which he or she works. To explicate further, Zelizer (2004, pp. 30-32) compared interpretations of journalism by journalists with that of academics. As an example, she used five metaphors to show that the way each group talks about journalism is influenced by their field of work (ibid.).

Zelizer pointed out that while journalists use metaphors like "sixth sense" (nose for news), container (space, news hole), mirror (that reflects reality - though contested), child (as in "put the news to bed", meaning complete the circle of news production or cast the news) and service (crusader role of journalism), to talk about journalism, a journalism scholar is more likely to discuss journalism in terms of it being a text, a profession and an institution, and as people and as a set of practices (ibid.). She observed that neither account is comprehensive because each of them only tells part of the story of what journalism represents. Zelizer $(1993,2004)$ posits that their interpretations were influenced by their background, in this case their field of work (ibid.). This concept presents journalists as a united front-one interpretive community in the way they perceive and describe their profession (Berkowitz 2000, cited in Carlson 2015, p. 3 ).

Viewing Zelizer's explanation of interpretive communities from the lenses of Fraser's (1992) conceptualisation of multiple public spheres, and Ornebring and Jonsson's (2004) extension of that concept to the press, I argue that though journalists have a shared understanding of their practice, which can make them function as one interpretive community, journalists can also function as multiple interpretive communities in discourses about journalism. Newspaper classification, ownership patterns and 
business model are examples of factors that can give birth to multiple publics within journalism's interpretive community. I argue that in debates about journalism, there can be multiple homogeneous public spheres with each homogeneous sphere standing as a united front on an issue of common concern. I refer to such multiple spheres of homogeneous discourses as sub-interpretive spheres. Multiple sub-interpretive spheres can arise from differences and similarities in the press' interpretations of journalistic paradigms such as press freedom and objectivity. The demarcation may or may not be along the lines of media outfits because they are spheres of discourses. The homogeneity of a sub-interpretive sphere does not preclude disagreements on certain issues within each homogeneous public. For example, though feminism features as a homogeneous public sphere, there are still different schools of thought among feminists (Tong 2014, pp. 1-6). Their uniting factor would, therefore, be a high degree of similarity in their expressions on an issue or argument.

In studies where homogeneous publics emerge within an interpretive community, a confederation pattern of analysis can be employed to fish out both collective and individual patterns in the coverage. Confederations are "loose governing arrangement $[\mathrm{s}]$ in which separate republics or nations join to coordinate foreign policy and defense but retain full control over their domestic affairs" (Jillson 2013, p. 63). Applying this to media studies, I define "confederation pattern of analysis" as a pattern of critique that allows analysis of media content both in groups (e.g. a group of newspapers) and individually (individual newspapers). This allows room for the identification of unique trends and styles within discourse. Using a confederation pattern of analysis, this book analyses newspapers in groups of discourse (sub-interpretive spheres) when they were united for certain causes and individually in areas where they had unique differences. That is because in the coverage of media policy, democracy is achieved when the press makes room for contestations among diverse competing discursive publics (Fraser 1992, p. 122, cited in Butsch 2007, p. 5).

\section{CONCLUSION}

The media are expected to carry out certain functions that are integral to the sustenance of democracy. One of such functions is to operate as a public sphere where citizens can participate in debates that can affect policy decisions. How the media facilitate debates in this space can affect the outcome of debates on policy. With regard to debates on media policy, a 
degenerated public sphere would produce a shallow and dumbed down debate with narrow perspectives that are shaped by self-interest. Such a public sphere would lack the creativity and robustness needed to generate discussions that can result in the establishment of an accountable press. The normative expectation is that the media should serve as a democratic public sphere, one that gives voice to all parties involved in a debate irrespective of their argument or their status in society. The exclusion or marginalisation of any of the parties involved from a debate on media policy will run contrary to "democracy's claim of universalism" (Dahlgren 1995; p. 36). The type of space or amount of coverage given ought not to be based on the media's self-interest. The media ought to function as a marketplace of ideas during debates on media policy (Milton 1644/1961; Mill 1859/1978).

The neoliberal press theory argues that for the press to function as a marketplace of ideas where diverse views can be aired without fear of suppression or oppression, it must be autonomous of the state (ibid.). In democratic societies, it is widely accepted that the press should be given the freedom it requires to check the powerful so that they do not abuse their powers. What is often contested is the level of autonomy necessary to fulfil this role. Should all types of state intervention in press regulation be viewed as a slippery slope to licensing of the press? Is this perspective a paradigm that needs to be reconsidered? Can some levels of state intervention help to check press bad behaviour? The theory of social democracy argues that a little bit of state intervention in press regulation may not necessarily result in the loss of press freedom. It posits that measures can be put in place to ensure that government does not overstep its bounds. This book argues that no side of the argument should be suppressed or marginalised in debates about media policy. A public sphere that gives proportionate access to arguments based on diverse ideologies would feature more robust debates and is more likely to generate more creative and effective ideas for media reform.

This chapter applies the public sphere concept to discourse. In agreement with Fraser's (1992) argument that multiple publics rather than a single central public sphere are closer to the democratic ideal, this chapter argues that debates on media policy should make room for multiple discursive publics. It points out that in debates about media policy, journalism would not necessarily function as one interpretive community. I am of the view that this is a good thing because it reflects plurality of views in the debate. As Fraser (1992) argues, within the public sphere, contestation rather than a consensus is closer to the democratic ideal. Problems may 
arise from a situation where one discursive public dominates the discussion. Such a situation is akin to Habermas' central public where consensus rather than contestation within the public sphere was depicted as the democratic ideal. This book posits that democracy is enhanced not with a single comprehensive discursive public sphere, but with a situation that makes room for contestations among diverse competing discursive publics.

\section{REFERENCES}

Allan, S. (2006). Online news: Journalism and the Internet. Maidenhead: Open University Press.

Aristotle. (2010). The politics (C. Lord, Trans.). Chicago: University of Chicago Press.

Badsey, S. (2013). The media and international security. London: Routledge.

Barber, B. R. (1999). Three scenarios for the future of technology and strong democracy. Political Science Quarterly, 113(4), 573-590.

Barry, M. C. (2011). The American republic: The fourth form of government. Bloomington: iUniverse.

Benhabib, S. (2002). The claims of culture: Equality and diversity in the global era. Princeton: Princeton University Press.

Bennett, W. L., \& Entman, R. M. (2001). Mediated politics: Communication in the future of democracy. Cambridge: Cambridge University Press.

Berkowitz, D. (2000). Doing double duty: Paradigm repair and the Princess Diana what-a-story. Journalism, $1(2), 125-143$.

Berlin, I. (1969). Four essays on liberty. Oxford: Oxford University Press.

Bettig, R. V., \& Hall, J. L. (2012). Big media, big money: Cultural texts and political economics (2nd ed.). Plymouth: Rowman \& Littlefield Publishers.

Biagi, S. (2014). Media/impact: An introduction to mass media. Boston: Cengage Learning.

Butsch, R. (2007). Media and public spheres. Hampshire: Palgrave Macmillan.

Carlson, M. (2015). Metajournalistic discourse and the meanings of Journalism: Definitional control, boundary work, and legitimation. Communication Theory, 26(4), 349-368.

Cheema, G. (2005). Building democratic institutions: Governance reform in developing countries. Bloomfield: Kumarian Press.

Christians, C. G., et al. (2009). Normative theories of the media: Journalism in democratic societies. Illinois: University of Illinois Press.

Commission on Freedom of the Press. (1947). A free and responsible press. Chicago: University of Chicago Press.

Craig, E. (2000). Concise Routledge encyclopedia of philosophy. London: Routledge.

Curran, J., \& Seaton, J. (2010). Power without responsibility: Press, broadcasting and the internet in Britain (7th ed.). London: Routledge. 
Cushion, S. (2012). The democratic value of news: Why public service media matter. Hampshire: Palgrave Macmillan.

Dahl, R. A. (1989). Democracy and its critics. London: Yale University Press.

Dahl, R. A., et al. (2003). The democracy sourcebook. London: MIT Press.

Dahlgren, P. (1995). Television and the public sphere: Citizenship, democracy and the media. London: Sage.

Davis, M. (2016). Neoliberalism, the culture wars and public policy. In C. Miller \& L. Orchard (Eds.), Australian public policy: Progressive ideas in the neoliberal ascendency (pp. 27-44). Bristol: Policy Press.

Dawes, S. (2013). Press freedom, privacy and the public sphere. Journalism Studies, 15(1), 17-32.

Department for Digital, Culture, Media \& Sport. (2019). The Cairncross review: A sustainable future for journalism. 12 February [Online]. Retrieved July 3, 2019, from https://assets.publishing.service.gov.uk/government/uploads/ system/uploads/attachment_data/file/779882/021919_DCMS_ Cairncross_Review_.pdf.

Ewald, J. (2013). Challenges for the democratisation process in Tanzania. Moving towards consolidation years after independence? Oxford: African Books Collective.

Fenton, N. (2011). Murdochgate and the News: We need to reframe media and the public interest [Online]. Retrieved September 15, 2014, from https://www. opendemocracy.net/ourkingdom/natalie-fenton/murdochgate-and-newswe-need-to-reframe-media-and-public-interest.

Franklin, B. (1997). Newszak and news media. London: Arnold.

Franklin, B. (2004). Packaging politics: Political communications in Britain's media democracy (2nd ed.). London: Arnold.

Franklin, B. (2008). Pulling newspapers apart: Analysing print journalism. London: Routledge.

Fraser, N. (1990). Rethinking the public sphere: A contribution to the critique of actually existing democracy. Social Text, 25/26, 56-80.

Fraser, N. (1992). Rethinking the public sphere: A contribution to the critique of actually existing democracy. In C. Calhoun (Ed.), Habermas and the public sphere (pp. 109-142). London: MIT Press.

Friedman, M. (1962). Capitalism and freedom. Chicago: Chicago University Press.

Garcia-Blanco, I., et al. (2009). Media agoras: Democracy, diversity, and communication. Newcastle upon Tyne: Cambridge Scholars Publication.

Graber, D. (2003). The media and democracy: Beyond myths and stereotypes. Annual Review of Political Science, 6, 139-160.

Habermas, J. (1989). The structural transformation of the public sphere: An inquiry into a category of bourgeois society. Cambridge: Polity Press.

Hallin, D. C., \& Mancini, P. (2004). Comparing media systems: Three models of media and politics. Cambridge: Cambridge University Press. 
Hartley, J. (2011). Communication, cultural and media studies: The key concepts. London: Routledge.

Harvey, D. (2005). A briefhistory of neoliberalism. Oxford: Oxford University Press. Hayek, F. A. (1944). The road to serfdom. London: Routledge.

Held, D. (1996). Models of democracy (2nd ed.). Cambridge: Polity Press.

Held, D. (2006). Models of democracy (3rd ed.). Cambridge: Polity Press.

Herman, E., \& Chomsky, N. (2008). Manufacturing consent: The political economy of the mass media. London: Random House.

Heywood, A. (2017). Political ideologies: An introduction (6th ed.). London: Palgrave Macmillan.

Humphreys, P. (1996). Mass media and media policy in Western Europe (European Policy Research Unit Series). Manchester: Manchester University Press.

Independent. (2016). The Independent becomes the first national newspaper to embrace a global, digital-only future. Independent, 12 February [Online]. Retrieved January 10, 2017, from http://www.independent.co.uk/news/ media/press/the-independent-becomes-the-first-national-newspaper-to-embrace-a-global-digital-only-future-a6869736.html.

Jillson, C. (2013). American government: Political development and institutional change. London: Routledge.

Keane, J. (2016). Money, capitalism and the slow death of social democracy. The Conversation, 14 May [Online]. Retrieved December 3, 2017, from http:// theconversation.com/money-capitalism-and-the-slow-death-of-socialdemocracy-58703.

Kovach, B., \& Rosenstiel, T. (2003). The elements of journalism: What newspeople should know and the public should expect. London: Atlantic Books.

Lee-Wright, P., et al. (2012). Changing journalism. London: Routledge.

Lichtenberg, J. (1990). Democracy and the mass media (pp. 102-135). Cambridge: Cambridge University Press.

Lightfoot, S. (2005). Europeanizing social democracy?: The rise of the party of European socialists. Oxford: Psychology Press.

Lincoln, A. (1863/2009). The Gettysburg address. London: Penguin.

Lipset, M. S., \& Lakin, M. J. (2004). The democratic century. Oklahoma: University of Oklahoma Press.

Livingstone, D. (2013). Black terror white soldiers: Islam, fascism of the new age. S.I: Sabilillah publications.

Manza, J., \& Uggen, C. (2006). Locked out: Felon disenfranchisement and American democracy. Oxford: Oxford University Press.

Mayes, C. (2015). The biopolitics of lifestyle: Foucault, ethics and healthy choices. London: Routledge.

McChesney, R. W. (2001). Global media, neoliberalism, and imperialism. Monthly Review: An Independent Socialist Magazine, 52(10) [Online]. Retrieved June 26, 2017, from https://monthlyreview.org/?s=Global+Media\%2C+Neoliberal ism\%2C+and+Imperialism\&submit=Search. 
McQuail, D. (2010). McQuail's mass communication theory (6th ed.). London: Sage.

Merrill, J. C. (2000). Democracy and the press: The reality and the myth. Media Asia, 27(4), 197-199.

Meyer, T., \& Hinchman, L. (2007). The theory of social democracy. Cambridge: Polity Press.

Mill, J. S. (1859/1978). On liberty. Indianapolis: Hackett.

Milton, J. (1644/1961). Areopagitica. London: Oxford University Press.

Mouffe, C. (2005a). On the political. London: Routledge.

Mouffe, C. (2005b). The return of the political. London: Verso.

Nerone, J., et al. (1995). Last rights: Revisiting four theories of the press. Urbana: University of Illinois Press.

Norris, P. (1999). Introduction: The growth of critical citizens? In P. Norris (Ed.), Critical citizens: Global support for democratic government (pp. 1-30). Oxford: Oxford University Press.

Ornebring, H., \& Jonsson, A. (2004). Tabloid journalism and the public sphere: A historical perspective on tabloid journalism. Journalism Studies, 5(3), 283-295.

Pavlik, J. (2001). Journalism and new media. Columbia: Columbia University Press.

Phelan, S. (2014). Neoliberalism, media and the political. London: Springer.

Pickard, V. (2013). Mending the gaps: Reconnecting media policy and media studies. In K. Gates (Ed.), Media studies futures (pp. 404-421). London: Blackwell.

Pickard, V. (2015). America's battle for democracy: The triumph of corporate libertarianism and the future of media reform. Cambridge: Cambridge University Press.

Plehwe, D., et al. (2006). Neoliberal hegemony: A global critique. London: Routledge.

Putnis, P. (2000). Newspapers as political instruments in media policy debate. Agenda: A Journal of Policy Analysis and Reform, 7(2), 99-112.

Richard, L., et al. (2009). Latin American democracy: Emerging reality or endangered species? London: Routledge.

Sartori, G. (1987). The theory of democracy revisited. London: Chatham House Publishing.

Saxer, C. (2013). From transition to power alternation: Democracy in South Korea, 1987-1997. London: Routledge.

Scammell, M. (2000). Introduction: Democracy and the media. In M. Scammell \& H. A. Semetko (Eds.), The media, journalism and democracy (pp. xx-xlix). Aldershot: Dartmouth.

Schlosberg, J. (2017). Media ownership and agenda control: The hidden limits of the information age. London: Routledge.

Schudson, M. (1992). Was there ever a public sphere? If so, when?: Reflections on the American case. In C. Calhoun (Ed.), Habermas and the public sphere (pp. 143-163). London: MIT Press. 
Schudson, M. (2008). Why democracies need an unlovable press. Cambridge: Polity Press.

Schumpeter, J. A. (1943). Capitalism, socialism, and democracy. London: George Allen \& Unwin Ltd.

Shoemaker, P. J., \& Reese, S. D. (2013). Mediating the message in the 21st century: A media sociology perspective. London: Routledge.

Siebert, F. S., et al. (1956). Four theories of the press: The authoritarian, libertarian, social responsibility, and soviet communist concepts of what the press should be and do. Chicago: University of Illinois Press.

Springer, S., et al. (2016). Handbook of neoliberalism. London: Routledge.

Stromback, J. (2005). In search of a standard: Four models of democracy and their normative implications for journalism. Journalism Studies, 6(3), 331-345.

Tong, R. (2014). Feminist thought: A more comprehensive introduction (4th ed.). Colorado: Westview Press.

Warner, M. (2002). Publics and counterpublics. The Quarterly Journal of Speech, $88(4), 413-425$.

Wolff, C. (2013). Functional representation and democracy in the EU: The European commission and social NGOs. Colchester: ECPR Press.

Zelizer, B. (1993). Journalists as interpretive communities. Critical Studies in Mass Communication, 10, 219-237.

Zelizer, B. (2004). Taking journalism seriously: News and the academy. London: Sage.

Open Access This chapter is licensed under the terms of the Creative Commons Attribution 4.0 International License (http://creativecommons.org/licenses/ by $/ 4.0 /$ ), which permits use, sharing, adaptation, distribution and reproduction in any medium or format, as long as you give appropriate credit to the original author(s) and the source, provide a link to the Creative Commons licence and indicate if changes were made.

The images or other third party material in this chapter are included in the chapter's Creative Commons licence, unless indicated otherwise in a credit line to the material. If material is not included in the chapter's Creative Commons licence and your intended use is not permitted by statutory regulation or exceeds the permitted use, you will need to obtain permission directly from the copyright holder.

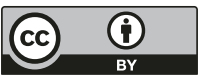

